\title{
INFLUENCE OF ANTI-BROWNING INHIBITORS AND BIODEGRADABLE PACKAGING ON THE QUALITY OF FRESH-CUT PEARS
}

\author{
Inta Krasnova*, Lija Dukal̦ska**, Dalija Segliṇa*, Inga Mišina*, and Daina Kārkliṇa** \\ * Latvia State Institute of Fruit Growing, Graudu iela 1, Dobele LV-3701, LATVIA; \\ inta.krasnova@Ivai.Iv \\ ** Latvia University of Agriculture, Faculty of Food Technology, Lielā iela 2, Jelgava LV-3001, LATVIA
}

Contributed by Dalija Seglina

\begin{abstract}
Pears usually are used as ingredients in the production of fresh-cut fruit salads. Fruit browning in the food industry is one of the main problems, and therefore, different anti-browning inhibitors are used to maintain the quality of fresh-cut pears. The aim of this study was to evaluate the use of Japanese quince (Chaenomeles japonica) juice (QJ) as an anti-browning agent for the pear (Pyrus communis) cultivar 'Belorusskaya Pozdnaya' and to compare its effect to that of ascorbic acid (AA) solution, which is typically used as an anti-browning agent. In addition, the effect of biodegradable packaging material on quality of treated pears during storage was assessed, in comparison with packaging in conventional polymer pouches. Diluted 20\% Japanese quince juice and $1.5 \%$ ascorbic acid solution were used as inhibitors of pear browning. Produce quality during storage of fresh-cut pears for ten days using biodegradable polilactid (PLA) containers with lids and VC999 BioPack PLA films coated with a barrier of pure silicon oxide (SiOx) was compared with that using conventional packaging with polyethylene (PE) film as a control. The quality of pears during storage was estimated by changes of colour brightness value $L^{*}$, whitening index (WI), firmness (N), $\mathrm{pH}$ value and total soluble solid content $\left(\right.$ Brix $\left.^{\circ}\right)$. The results showed that colour of fresh-cut pears was maintained better using biodegradable packaging materials and using the control anti-browning agent ascorbic acid. After nine storage days, the brightness $L^{*}$ value of fresh cut pears was significantly lower when conventional packaging material (PE film pouches) and treatment with Japanese quince juice was used.
\end{abstract}

Key words: ascorbic acid, Japanese quince, anti-browning, pears, biodegradable packaging.

\section{INTRODUCTION}

In recent years the market for fresh-cut or minimally processed and chilled ready-to-eat products has grown in response to evolving consumer demand and a trend toward healthier foods (Lamikanra, 2002). The major problem is that the shelf life of these commodities is very short, usually not exceeding one to three days. Fruit processing promotes their faster physiological deterioration and biochemical changes, also microbial spoilage of the final product, which may result in a degradation of its colour, texture and flavour, even when only slight processing operations are used (O'Beirne et al., 2003). The visual appearance and colour are the main characteristics that attract consumer attention and affect their choice (Barrett et al., 2010).

Fresh fruit browning is one of the fundamental problems faced in fruit processing steps and is also a quality indicator for the control of fresh fruit salad during shelf life. Nevertheless, the browning caused by enzyme oxidation leads not only to the deterioration of appearance of the products, but also to the decline of their nutritional value (Toivonen and Brummell, 2008).

Several scientists have pointed out that a major problem during storage is a decrease of fresh cut fruit firmness, which is related to action of endogenous enzymes on cell walls degradation and growth of microorganisms. The changes of fruit cell walls depend on content of protopectin and activity of enzymes like polygalacturonase, methylestherases, celulase and pectinase (Cheng et al., 2009). During fruit cutting enzymes are released, and in the presence of oxygen they accelerate endogenous processes and cause physical reactions in the cells leading to softer structure of fruit flesh (Prasanna et al., 2007; Ferreira et al., 2008).

Different surface coatings, like maltodextrin, methylcellulose, Semperfresh TM made on the basis of sucrose polyesters, soy protein, pectin, gelatine, alginate, shellac, whey protein concentrate, and bee wax, of fresh-cut fruit have 
been explored in various studies (Lee et al., 2003; OmsOliu et al., 2008; Oms-Oliu et al., 2010). Often, in order to reach a higher efficiency of the coatings, combinations of several treatments are used (Rojas-Graü et al., 2009; Olivas et al., 2007). Suttirak and Manurakchinakorn (2010) in their research used ascorbic, citric and oxalic acids, which are natural anti-browning agents and generally recognized as safe (GRAS). The scientists noted that browning of fresh-cut apples and mango could be effectively eliminated using oxalic acid in combination with ascorbic acid or citric acid (Suttirak and Manurakchinakorn, 2010). Successful results were obtained in studies by Xiao et al. (2010) with fresh cut pears, where rosemary extract and chitosan coating in various combinations were used against enzymatic browning. That treatment reduced permeability of cell membranes and caused slower respiration of pear pieces. As a result, the treated fruits had lower weight losses, higher content of vitamin $\mathrm{C}$ and colour was preserved better compared to the control. Ascorbic acid is a natural component in fresh fruits and vegetables and greatly accepted as an important nutrient for human health (Pernice et al., 2009). The most frequent alternative to sulphite is ascorbic acid, which is generally recognized by the U.S. Food and Drug Administration (FDA) as a safe (GRAS) antioxidant for use on fruits and vegetable to prevent browning. Ascorbic acid (L-ascorbic acid) and its various neutral salts and other derivatives have been the leading GRAS antioxidants for use on fruit and vegetables and in fruit juices, for the prevention of browning and other oxidative reactions. Ascorbic acid also acts as an oxygen scavenger, removing molecular oxygen in polyphenol oxidase reactions. Polyphenol oxidase inhibition by ascorbic acid has been attributed to the reduction of enzymatically formed $o$-quinones to their precursor diphenols (Özoglu and Bayindirli, 2002; Rojas-Graü et al., 2006; Rico et al., 2007; Jeong et al., 2008).

Mostly various salts (sodium chlorite, acidified sodium chlorite, ascorbate, isoascorbate, citrates, chelates, calcium chloride, sodium boron, and acetylcysteine), acids (ethylene diamine tetra acetic acid, salicylic acid, cinnamic acid, ascorbic acid, citric acid, and oxalic acid compositions) or specific enzyme inhibitors (4-hexylresorcinol, glutathione, etc.) are used as anti-browning inhibitors (Rojas-Graü et al., 2009; Oms-Oliu et al., 2010; Gomes et al., 2010). They are chemically derived inhibitors, and nowadays consumers are paying attention not only to fresh-cut product appearance and shelf life, but also critically evaluate the additives used in fruit processing for colour and texture preservation (Corbo et al., 2009). Therefore, in recent years research has been focused on the study of naturally occurring inhibitors. Several studies have demonstrated the prevention of freshcut fruit browning by the antioxidant Natureseal ( ${ }^{\circledR}$ AS5, which is produced from natural substances (Abbott et al., 2004; Rößle et al., 2009; Krasnova et al., 2012). Jeon and Zhao (2005) explored different flower origin honeys against browning processes of fresh-cut apples. The results showed that honey could be used as an anti-browning inhibitor by preserving the high quality of fresh-cut fruit. There is insuficient information about application of natural juices in browning prevention. Perera et al. (2010) reported pineapple juice usage for the treatment of apples 'Granny Smith' and 'Pink Lady'. After treatment with $50 \%$ pineapple juice, polyphenol oxidase was inhibited by $30 \%$ in 'Granny Smith' and for $40 \%$ in 'Pink Lady' apple slices. Other studies showed that treatment with $20 \%$ rhubarb juice solution declines apple browning for several hours (Son et al., 2000).

Another factor that must be considered in processing of fresh-cut products is the packaging. Fresh salad storage time and quality is significantly dependent on the packaging material and its barrier properties - permeability of $\mathrm{O}_{2}$ and $\mathrm{CO}_{2}$ (Montanez et al., 2010). Packaging is an integral and determinant part of the industrial and commercial food supply chain (Platt et al., 2006). Packaging materials, including biodegradable polymers, can be used to extend the shelf life extension of fresh-cut products. At present, polylactid (PLA) is the most widely used biodegradable polymer for fresh-food applications. Nowadays, new biodegradable materials have been produced with improved barrier properties, for example VC999 BioPack lidding film PLA, coated with a barrier of pure silicon oxide (Perez-Gago et al., 2006). Alternatively, polylactide (PLA) containers have properties that enable their use as a substitute for commercial clamshell containers. PLA is biodegradable, recyclable, compostable, made $100 \%$ from renewable resources, approved by the Food and Drug Administration (FDA) for contact with food, and has similar physical and mechanical properties to those of Polyethylene terephtalate (PET) and oriented polystyrene (PS) (Auras et al., 2004) In this work the suitability of biodegradable films as packaging materials for fresh-cut pears was addressed. In previous work, the authors explored the influence of low environmental impact packaging materials on the respiration rate of fresh fruit salad.

The objective of this research was to evaluate the use of watery Japanese quince (Chaenomeles japonica) juice as an anti-browning treatment source of pears and to compare its effect with the usually used anti-browning method by ascorbic acid solution. Also, the use of biodegradable packaging material to preserve quality of treated pears during storage was assessed, in comparison with that of conventional PE pouches.

\section{MATERIALS AND METHODS}

Materials used for experiments. The experiments were carried out in laboratories of the Latvia State Institute of Fruit Growing in 2010. The object of the research was pear (Pyrus communis) of cultivar 'Belorusskaya Pozdnaya' harvested in Dobele (Latvia State Institute of Fruit Growing) in autumn 2009. After harvesting, the fruits were stored for four months in a warehouse at temperature $+41{ }^{\circ} \mathrm{C}$ and relative humidity (RH) $90 \%$. Before experiments, the fruits were removed from the storehouse and ripened for five days at indoor temperature $18-20{ }^{\circ} \mathrm{C}$. Before processing, the fruits were washed in running water, peeled with a sharp 
stainless steel knife, cored and cut into $1-1.5 \mathrm{~cm}$ cubical pieces (average mass of each $7 \pm 1 \mathrm{~g}$ ), and immediately for ten minutes immersed in the prepared anti-browning agent, and then dried on a sieve. Watered Japanese quince juice (QJ) and ascorbic acid (AA) solutions were used as browning inhibitors. Ascorbic acid solution (1.5\%) was prepared by dissolving $1.5 \mathrm{~g}$ of ascorbic acid (Fluka) in $85 \mathrm{ml}$ of water. Diluted Japanese quince juice (concentration 20\%) was made by mixing of $20 \mathrm{ml}$ natural juice and $80 \mathrm{ml}$ water, following by pasteurisation at temperature $95{ }^{\circ} \mathrm{C}$ and cooling till ambient temperature $20 \pm 2{ }^{\circ} \mathrm{C}$.

Packaging and storage of samples. Fresh-cut pear produce quality during storage was compared using two types of biodegradable materials — biodegradable polilactid (PLA) containers with lids and pouches composed of VC999 BioPack PLA films coated with a barrier of pure silicon oxide $(\mathrm{SiOx})$, and conventional packaging - polyethylene (PE) film pouches $(185 \mathrm{~mm} \times 205 \mathrm{~mm}$, thickness of $65 \mu \mathrm{m})$ as a control.

The treated samples $(200 \pm 10 \mathrm{~g})$ were placed in each PE and VC999 BioPack PLA film pouches $(185 \mathrm{~mm} \times 205$ $\mathrm{mm}$, thickness of $50 \mu \mathrm{m})$ and hermetically sealed in air ambiance by a vacuum sealing machine Faverani MOD.350B (Faverani, Italia) and in sample $(160 \pm 10 \mathrm{~g})$ were also placed in PLA containers $(100 \mathrm{~mm} \times 80 \mathrm{~mm} \times 45 \mathrm{~mm}$, thickness $300 \mu \mathrm{m}$ ) and closed by non-hermetical lids.

Experiment design. Samples were stored in a Commercial Freezer/Cooler at temperature $+4.0 \pm 0.5^{\circ} \mathrm{C}$, controlled by a MINILog Gresinger. During storage for nine days two packages of each treatment were removed every three days for measurement of paramaters with three replicates. Features of the materials used in experiments and structure of performed experiments is shown in Figure 1.

Physical and chemical analyses. Colour of pear samples was measured by a CIE L*a*b* colour system using a Tristimulus Colorimeter, measuring Hunter colour parameters by Colour Tec PCM/PSM. Colour values were recorded as $\mathrm{L}^{*}$ (brightness) from $\mathrm{L}^{*}=0$ (black) through grey to $\mathrm{L}^{*}=$ 100 (white); $a^{*}$ (-a, greenness, +a, redness) from -a* (green)

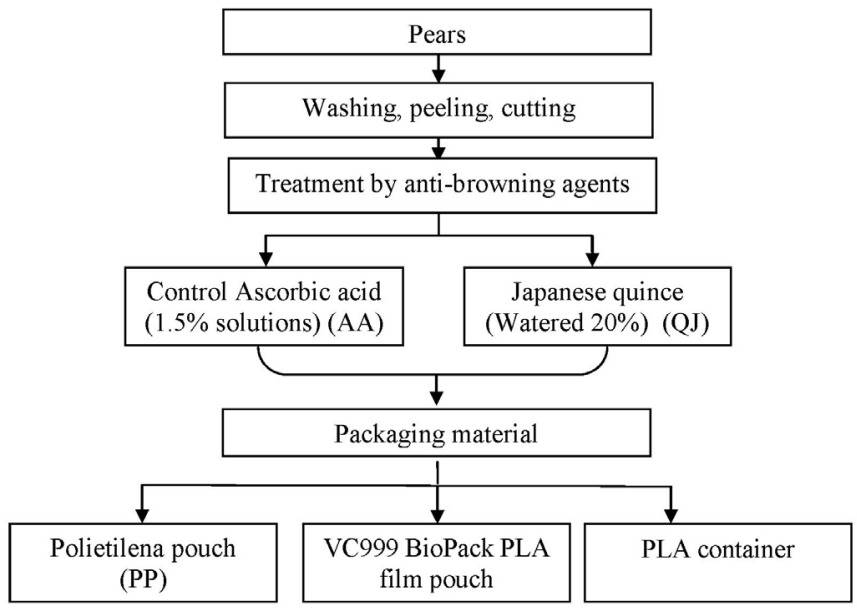

Fig. 1. The scheme of performed experiment. through grey to $+a^{*}$ (red) and $b^{*}(-b$, blueness, $+b$, yellowness) from $-b^{*}$ (blue) through grey to $+b^{*}$ (yellow). The colour measurements were performed on ten fruit pieces in three replication for each and expressed as whiteness index (WI), which was calculated according to equation (1) using colour indices $\mathrm{L}^{*}, \mathrm{a}^{*}$ and $\mathrm{b}^{*}$ as suggested by Albanese:

$W I=100-\sqrt{\left(100-L^{*}\right)^{2}+a^{* 2}+b^{* 2}}$,

where:

$L^{*}, a^{*}, b^{*}-$ colour measurements of the fruit samples.

Flesh firmness $(\mathrm{N})$ was determined using a digital penetrometer TMS-PRO (Food Technology Corporation, USA). A nozzle diameter of $4 \mathrm{~mm}$, penetration depth of $6 \mathrm{~mm}$ and speed measurement of $600 \mathrm{~mm} \mathrm{~min}^{-1}$ was used.

$\mathrm{pH}$ was determined using a $\mathrm{pH}$ meter 3510 (Jenway, England) according to the standard LVS EN 1132:2001 "pH Determination of Fruit and Vegetable Juice".

Soluble solids content (Brix, ${ }^{\circ}$ ) was determined according to LVS EN 12143:2001 using a refractometer (ATAGO, Japan).

Statistical analysis. The results were processed by mathematical and statistical methods. Statistics for the completely randomised design were determined using the General Linear Model (GLM) procedure with SPSS 15 software package. Two-way analyses of variance $(P \leq 0.05)$ was used to determine significance of differences between whitening index and firmness changes of pears during storage in biodegradable and conventional packaging materials after antibrowning treatment with Japanese quince and ascorbic acid as a control.

\section{RESULTS}

The surface brightness $\mathrm{L}^{*}$ dynamics of fresh-cut pear's treated with anti-browning agents ascorbic acid (AA) and Japanese quince juice (QJ) is represented in the Figure 2. The $\mathrm{L}^{*}$ value was influenced by the anti-browning treatment agent and differed significantly $(P<0.05)$ between treatments. Pears treated with ascorbic acid were lighter in colour than those treated with Japanese quince juice (QJ). The effect of conventional PE packaging film on decrease of brightness $\mathrm{L}^{*}$ value was higher than that of the biodegradables by more than $9.0 \%$. The difference of $\mathrm{L}^{*}$ value among investigated pear samples in biodegradable packaging after nine storage days was insignificant $(P=0.015)$, while samples packed in PE film pouches and treated with Japanese quince juice became darker. The results showed that colour of fresh-cut pears during storage was better preserved using biodegradable packaging materials and the control anti-browning agent ascorbic acid.

The results of colour changes expressed as whitening index WI showed similar results as those of colour brightness L* value dynamics (Fig. 2). Significant differences in WI value 


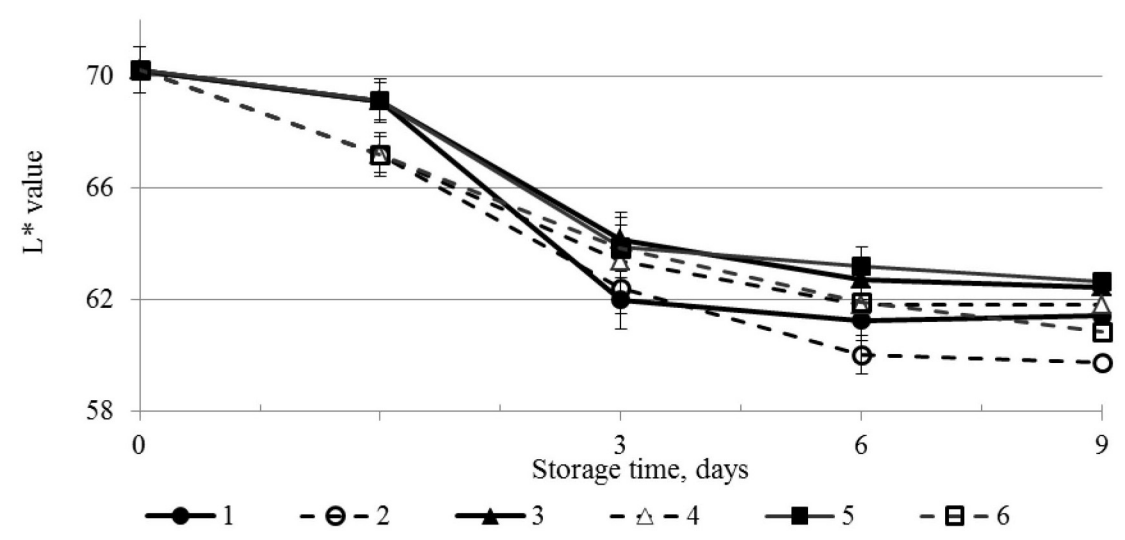

Fig. 2. Colour brightness value $\mathrm{L}^{*}$ of fresh-cut pears during storage in different packaging materials: 1, packaging in PE pouches (AA); 2, packaging in PE pouches $(\mathrm{QJ}) ; 3$, packaging in PLA containers (AA); 4, packaging in PLA containers (QJ); 5, packaging in VC999 BioPack PLA film pouches (AA); 6, packaging in VC999 BioPack PLA film pouches (QJ). did not differ between pear samples packed in VC999 BioPack PLA film pouches (AA) and in PLA containers (AA). The WI value of fresh cut pears after nine storage days when packed in conventional packaging material (PE film pouches) treated by Japanese quince juice was significantly lower $(P<0.05)$ (Fig. 3). Better results in browning inhibition during storage were obtained using ascorbic acid (AA) and packaging in biodegradable PLA containers and VC999 BioPack PLA film pouches. The WI value of pear samples treated with Japanese quince juice and stored for nine days in PE film pouches significantly differed from all other samples $(P=0.029)$.

Firmness during storage significantly depended on storage time $(P<0.05)$. The flesh firmness of the investigated pear samples gradually decreased during storage for nine days. Before treatment, the firmness of fresh-cut pear cubes was on average $18.4 \pm 1.9 \mathrm{~N}$ (Fig. 4). Firmness of pears during storage differed between treatments. The least change in firmness of pears was observed for in both biodegradable material packaging treatments and was similar for both anti-browning solutions (average $7.3 \%$ for pears treated with Japanese quince juice and $7.9 \%$ for those treated with ascorbic acid). A larger decrease of firmness decrease was observed when pears were stored in PE film pouches: $19.0 \%$ when treated with Japanese quince juice and $19.3 \%$ when treated with ascorbic acid.

Acidity can act on respiration processes of fresh-cut fruits. Analysis of variance indicated that $\mathrm{pH}$ of pear samples somewhat increased during storage and at the end of storage slightly differed between packaging material treatment $(P<$ $0.05)$. Increase of $\mathrm{pH}$ of samples in $\mathrm{PE}$ film packaging was slightly higher (4.59 (AA) and 4.61 (QJ) to 4.94) than in samples stored in biodegradable packaging (4.82 to 4.85 ) (Table 1).
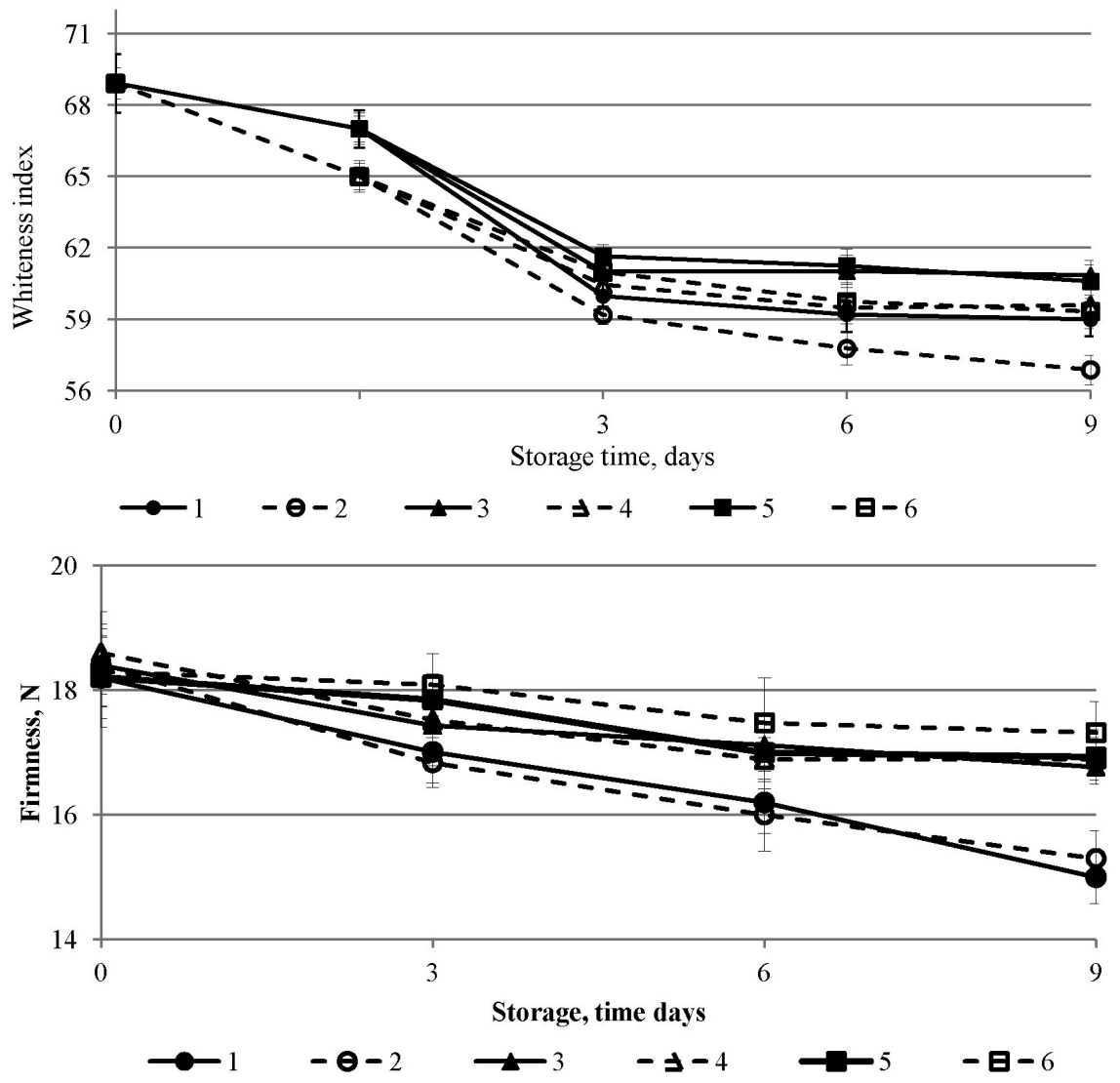

Fig. 3. Whiteness index of fresh-cut pears during storage in different packaging materials: 1 , packaging in $\mathrm{PE}$ pouches (AA); 2, packaging in $\mathrm{PE}$ pouches $(\mathrm{QJ})$; 3, packaging in PLA containers (AA); 4, packaging in PLA containers (QJ); 5, packaging in VC999 BioPack PLA film pouches (AA); 6, packaging in VC999 BioPack PLA film pouches $(\mathrm{QJ})$.
Fig. 4. Firmness of fresh-cut pears during storage in different packaging materials: 1 , packaging in PE pouches (AA); 2, packaging in PE pouches (QJ); 3, packaging in PLA containers (AA); 4, packaging in PLA containers (QJ); 5, packaging in VC999 BioPack PLA film pouches (AA); 6, packaging in VC999 BioPack PLA film pouches (QJ). 
pH VALUE OF FRESH-CUT PEARS DURING STORAGE IN DIFFERENT PACKAGING MATERIALS

\begin{tabular}{c|c|c|c|c}
\hline \multirow{2}{*}{$\begin{array}{c}\text { Sam- } \\
\text { ples }\end{array}$} & 0 & 3 & 6 & 9 \\
\cline { 2 - 6 } & 0 & \multicolumn{5}{|c}{ Storage time, days } \\
\hline $1^{* * *}$ & $12.54^{*} \pm 0.36^{\mathrm{b}^{* *}} 11.93 \pm 0.18^{\mathrm{c}}$ & $11.84 \pm 0.23 \mathrm{a}$ & $11.75 \pm 0.17^{\mathrm{b}}$ \\
2 & $12.44 \pm 0.32^{\mathrm{a}}$ & $11.85 \pm 0.21^{\mathrm{b}}$ & $11.75 \pm 0.42 \mathrm{a}$ & $11.66 \pm 0.20^{\mathrm{a}}$ \\
3 & $12.54 \pm 0.36^{\mathrm{b}}$ & $12.09 \pm 0.22^{\mathrm{d}}$ & $12.05 \pm 0.2 \mathrm{c}$ & $11.97 \pm 0.22^{\mathrm{d}}$ \\
4 & $12.44 \pm 0.32^{\mathrm{a}}$ & $12.01 \pm 0.28^{\mathrm{d}}$ & $11.93 \pm 0.17 \mathrm{~b}$ & $11.84 \pm 0.18^{\mathrm{c}}$ \\
5 & $12.54 \pm 0.36^{\mathrm{b}}$ & $11.73 \pm 0.11^{\mathrm{a}}$ & $11.83 \pm 0.15 \mathrm{a}$ & $11.81 \pm 0.31^{\mathrm{c}}$ \\
6 & $12.44 \pm 0.32^{\mathrm{a}}$ & $12.1 \pm 0.26^{\mathrm{d}}$ & $12.05 \pm 0.27 \mathrm{c}$ & $11.88 \pm 0.20^{\mathrm{c}}$
\end{tabular}

*Each value is the mean of 12 determinations, $\pm \mathrm{SD},(\mathrm{n}=12)$. ${ }^{* *}$ Values, marked with the same letter in a column, are not significantly different at $P<0.05$. $^{* * *} 1$, packaging in PE pouches (AA); 2 , packaging in PE pouches (QJ); 3, packaging in PLA containers (AA); 4, packaging in PLA containers (QJ); 5, packaging in VC999 BioPack PLA film pouches (AA); 6, packaging in VC999 BioPack PLA film pouches (QJ).

Table 2

TOTAL SOLUBLE SOLID CONTENT (Brix, ${ }^{\circ}$ ) OF FRESH-CUT PEARS DURING STORAGE IN DIFFERENT PACKAGING MATERIALS

\begin{tabular}{|c|c|c|c|c|c|c|c|c|}
\hline \multirow{2}{*}{$\begin{array}{c}\text { Sam- } \\
\text { ples }\end{array}$} & \multicolumn{8}{|c|}{ Storage time, days } \\
\hline & & 0 & & 3 & & 6 & & 9 \\
\hline 1 & 4.59 & $\pm 0.02^{\mathrm{a}}$ & 4.78 & $\pm 0.01^{\mathrm{a}}$ & 4.92 & $\pm 0.01^{\mathrm{a}}$ & 4.94 & $\pm 0.02^{c}$ \\
\hline 2 & 4.61 & $\pm 0.01^{\mathrm{b}}$ & 4.79 & $\pm 0.01^{\mathrm{ab}}$ & 4.92 & $\pm 0.10^{\mathrm{a}}$ & 4.94 & $\pm 0.02^{\mathrm{c}}$ \\
\hline 3 & 4.59 & $\pm 0.01^{\mathrm{a}}$ & 4.79 & $\pm 0.03^{\mathrm{ab}}$ & 4.83 & $\pm 0.01^{\mathrm{b}}$ & 4.85 & $\pm 0.01^{b}$ \\
\hline 4 & 4.61 & $\pm 0.02^{\mathrm{b}}$ & 4.78 & $\pm 0.02^{\mathrm{ab}}$ & 4.84 & $\pm 0.00^{c}$ & 4.85 & $\pm 0.02^{b}$ \\
\hline 5 & 4.59 & $\pm 0.02^{\mathrm{a}}$ & 4.79 & $\pm 0.01^{\mathrm{ab}}$ & 4.83 & $\pm 0.00^{\mathrm{b}}$ & 4.79 & $\pm 0.01^{\mathrm{a}}$ \\
\hline 6 & 4.61 & $\pm 0.01^{\mathrm{b}}$ & 4.8 & $\pm 0.01^{\mathrm{c}}$ & 4.82 & $\pm 0.00^{\mathrm{b}}$ & 4.84 & $\pm 0.01^{b}$ \\
\hline
\end{tabular}

*Each value is the mean of 12 determinations, $\pm \mathrm{SD},(\mathrm{n}=12) .{ }^{* *}$ Values, marked with the same letter in a column, are not significantly different at $P<0.05$. ${ }^{* * *} 1$, packaging in $\mathrm{PE}$ pouches (AA); 2 , packaging in $\mathrm{PE}$ pouches (QJ); 3, packaging in PLA containers (AA); 4, packaging in PLA containers (QJ); 5, packaging in VC999 BioPack PLA film pouches (AA); 6 , packaging in VC999 BioPack PLA film pouches (QJ)

The total soluble solid contents of fresh-cut pears packed in various packaging materials are presented in Table 2. Total soluble solid content slightly decreased in all studied samples on average by about 12.5 to 11.8 Brix $^{\circ}$.

\section{DISCUSSION}

The intensity of fresh-cut fruit browning usually is described by the value of colour parameter $\mathrm{L}^{*}$ and whiteness index (WI). It was noted that both colour brightness value $\mathrm{L}^{*}$ and Whiteness index (WI) equally describe the changes in fresh-cut apple colour. Substantial colour changes mostly occur during the first days of storage (Mao et al., 2007; Lu et al., 2007).

In the last few years, the use of PLA as a packaging material has increased in Europe, Japan, and the United States, mainly in the area of fresh produce (Arvanitoyannis and Kasaveti, 2007). Reduced respiration rate leads to lower en- zymatic browning reactions (Rodriguez-Aguilera and Oliveira, 2009; Sandhya, 2011). Similar results were obtained by scientists of Latvia when testing fresh-cut apple pieces treated with $5 \%$ solution of Natureseal ${ }^{\circledR}$ AS5 (Krasnova et al., 2012). Perera et al. investigated the combined effect of high pressure processing (HPP) treatment and pineapple juice prevention of enzymatic browning of fresh cut Granny Smith and Pink Lady apples (Perera et al., 2010). For both apple varieties the samples treated with the highest concentration of pineapple juice $50 \%$ and the longest HPP treatment time $5 \mathrm{~min}$ had the lowest $\Delta \mathrm{E}$ and the least browning score after $5 \mathrm{~h}$ of air exposure. A non-volatile organic acid in pineapple juice was the major inhibitor of enzymatic browning in apple products (Perera et al., 2010; Dong et al., 2000). Pineapple juice, pineapple shell extract and rice bran extract have been used as banana anti-browning agents (Theerakulkaita and Sukhonthara, 2008). The $L^{*}$ value of banana slice treated with rice bran extract was not significantly higher than that treated with Pineapple juice and both had ability to reduce browning values in the banana slices.

Decrease of flesh firmness was found (Xiao et al., 2010) following anti-browning treatment of cut pears with rosemary extract, chitosan and their combinations. During 3-day storage the firmness of treated pears decreased from 5.5 to $7.3 \%$. This decrease is related with ripening processes in storage, when the cell structure of flesh firmness is changed due to reactions of polysaccharide hydrolysis (Prasanna et al., 2007; Ferreira et al., 2008).

The increase of $\mathrm{pH}$ can be explained by increased breathing intensity after peeling and slicing of fruits (Rocha and Morais, 2003). The organic acids along with other compounds take part in respiration, and as a result the total content of acids decreases and pH value increases (Bico et al., 2009).

The observed decrease of total soluble content in all studied samples was caused by physiological and biochemical processes that accelerated after fresh fruit peeling and cutting. Organic acids, pectin substances and other sugars participating in these reactions stimulate the decrease of soluble solids during storage (Rocha and Morais, 2003). However, the content of soluble solids in the fresh cut-pears during the experiment did not vary throughout storage and were not significantly influenced by time, packaging material and anti-browning treatment agent $(P>0.05)$. These results are in accordance with those found by Soliva-Fortuny et al. (2002).

The results of this study showed that colour of fresh-cut pears was better maintained using biodegradable packaging materials and by the control anti-browning agent ascorbic acid. Following nine storage days, the brightness $\mathrm{L}^{*}$ value of fresh cut pears was significantly lower in the treatment with conventional packaging material (PE film pouches) and Japanese quince juice.

The treatment of fruits by diluted Japanese quince (Chaenomeles japonica) juice provided higher firmness after 
treatment. The least change of firmness was observed for pears packed in both biodegradable materials with either anti-browning solution, while a considerably greater descrease of pear firmness was observed in the PE film pouch treatment.

$\mathrm{pH}$ of pear samples somewhat increased during storage and at the end of storage slightly differed among packaging material treatments, while total soluble solid content slightly decreased in all samples.

\section{ACKNOWLEDGEMENTS}

This research and publication were prepared within the framework of the ESF Project "Scientific capacity building in fruit-growing, forestry and information technology sectors, providing research on environmentally friendly growing strategies, product development and introduction aided by computer technologies" Contract

No. 2009/0228/1DP/1.1.1.2.0/09/APIA/VIAA/035.

\section{REFERENCES}

Abbott, J. A., Saftner, R. A., Gross, K. C., Vinyard, B. T., Janick, J. (2004). Consumer evaluation and quality measurement of fresh-cut slices of 'Fuji,' 'Golden Delicious', 'GoldRush,' and 'Granny Smith' apples. Postharv. Biol. Technol., 33, 127-140.

Albanese, D., Cinquanta, L., Matteo, M. (2007). Effects of an innovative dipping treatment on the cold storage of minimally processed Annurca apples. Food Chem., 105, 1054-1060.

Auras, R., Harte, B., Selke, S. (2004). An overview of polylactides as packaging materials. Macromol. Biosci., 4, 835-864.

Arvanitoyannis, I. S., Kassaveti, A. (2007). In: Chiellini, E. (Ed.). Consumer Attitude to Food Packaging and the Market for Environmentally-compatible Products in Environmentally-compatible Food Packaging (pp. 161181). Cambridge: Woodhead Publishing, UK.

Barrett, D. M., Beaulieu, J. C., Shewfelt, R. (2010). Color, flavor, texture, and nutritional quality of fresh-cut fruits and vegetables: Desirable levels, instrumental and sensory measurement, and the effects of processing. Crit. Rev. Food Sci. Nutr., 50, 369-389.

Bico, S. L. S., Raposo, M. F. J., Morais, R. M. S. C., Morais, A. M. M. B. (2009). Combined effects of chemical dip and/or carrageenan coating and/or controlled atmosphere on quality of fresh-cut banana. Food Control, 20, 508-514.

Cheng, G., Duan, X., Jiang, Y., Sun, J., Yang, S., Yang, B. (2009). Modification of hemicellulose polysaccharides during ripening of postharvest banana fruit. J. Food Chem., 115 (1), 43-47.

Corbo, M. R., Bevilacqua, A., Campaniello, D., D’Amato, D., Speranza, B., Sinigaglia, M. (2009). Prolonging microbial shelf life of foods through the use of natural compounds and non-thermal approaches: A review. Int. J. Food Sci. Technol., 44 (2), 223-241.

Dong, X., Wrolstad, R. E., Sugar, D. (2000). Extending shelf life of fresh-cut pears. J. Food Sci., 65 (1), 181-186.

Ferreira, D., Lopes da Silva, J. A., Conceicao Santos, G. P., Delgadillo, I., Coimbra, M. A. (2008). Effect of sun-drying on microstructure and texture of S. Bartolomeu pears (Pyrus communis L.). Eur. Food Res. Technol., 226 (2), 1545-1552.

Gomes, M. H., Fundo, J. F., Santos, S., Amaro, L. A., Almeida, D. P. F. (2010). Hydrogen ion concentration affects quality retention and modifies the effect of calcium additives on fresh-cut 'Rocha' pear. Postharv. Biol. Technol., 58, 239-246.
Hosoda, H., Inoue, E., Iwahashi, Y., Sakaue, K., Tada, M., Nagata, T. (2005). Inhibitory effect of sulfides on browning of apple slice. J. Japan. Soc. Food Sci. Technol., 52, 120-124.

Jeon, M., Zhao, Y. (2005). Honey in combination with vacuum impregnation to prevent enzymatic browning of fresh-cut apples. Int. J. Food Sci. Nutr., 56, $165-176$

Jeong, H. L., Jin, W. J., Kwang, D. M., Kee, J. P. (2008). Effects of anti-browning agents on polyphenol oxidase activity and total phenolics as related to Browning of Fresh-Cut 'Fuji' Apple. Asean Food J., 15 (1), 79-87.

Krasnova, I., Dukalska, L., Seglina, D., Juhnevica, K., Sne, E., Karklina, D. (2012). Effect of passive modified atmosphere in different packaging materials on fresh-cut mixed fruit salad quality during storage. World Acad. Sci. Eng. Technol., 67, 1095-1104. https://www.waset.org/journals/waset/v67/v67-197.pdf

Lamikanra, O. (2002). Preface. In: Lamikanra, O. (Ed.). Fresh-cut fruits and vegetables. Science, technology and market (pp. 277-282). Cambridge, UK Boca Raton, FL: CRC Press.

Lee, J. Y., Park, H. J., Lee, C. Y., Choi W. Y. (2003). Extending shelf-life of minimally processed apples with edible coatings and antibrowning agents. LWT- Food Sci. Technol., 36, 323-329.

Lu, S., Luo, Y, Turner, E., Feng, H. (2007). Efficacy of sodium chlorite as an inhibitor of enzymatic browning in apple slices. Food Chem., 104, 824-829.

Mao, L., Lu, F., Wang, G. (2007). Application of 1-methylcyclopropene reduces wound responses and maintains quality in fresh-cut apple. Asia Pac. J. Clin. Nutr., 16, 111-115.

Montanez, J. C., Rodriguez, F. A. S., Mahajan, P. V., Frias, J. M. (2010). Modelling the gas exchange rate in perforation-mediated modified atmosphere packaging: Effect of the external air movement and tube dimensions. J. Food Eng., 97 (1), 79-86.

O'Beirne, D., Francis, G. A. (2003). Reducing the pathogen risk in MAP prepared produce. In: Ahvenainen, R. (Ed.). Novel Food Packaging Techniques (pp. 231-286). Cambridge, UK: Woodhead Publishing Limited.

Olivas, G. I., Mattinson, D. S., Barbosa-Canovas, G. V. (2007). Alginate coatings for preservation of minimally processed 'Gala' apples. Postharv. Biol. Technol., 45, 89-96.

Oms-Oliua, G., Rojas-Graua, M. A., Gonzalezb, L. A., Varelac, P., Soliva-Fortunya, R., Hernando, M. I., Perez Munuera, I., Fiszmanc, S., Martin-Bellosoa, O. (2010). Recent approaches using chemical treatments to preserve quality of fresh-cut fruit: A review. Postharv. Biol. Technol., 57, 139-148.

Oms-Oliu, G., Soliva-Fortuny, R., Martin-Belloso, O. (2008). Edible coatings with antibrowning agents to maintain sensory quality and antioxidant properties of fresh-cut pears. Postharv. Biol. Technol., 50, 87-94.

Özoglu, H., Bayindirli, A. (2002). Inhibition of enzymatic browning in cloudy apple juice with selected antibrowning agents. Food Control., 13, 213-221.

Perera, N., Gamage, T. V., Wakeling, L., Gamlath, G. S., Versteeg, C. (2010). Colour and texture of apples high pressure processed in pineapple juice. J. Innovat. Food Sci. Emerging Technol., 11, 39-46.

Perez-Gago, M. B., Serra, M., Del Rio, M. A. (2006). Color change of fresh-cut apples coated with whey protein concentrate-based edible coatings. Postharv. Biol. Technol., 39, 84-92.

Pernice, R., Borriello, G., Ferracane, R., Borrelli, R. C., Cennamo F., Ritieni A. (2009). Bergamot: A source of natural antioxidants for functionalized fruit juices. Food Chem., 112, 545-550.

Platt, D. K. (2006). Biodegradable polymers. Market report, RAPRA Technologies. A Smithers group Company. Retrieved 21 September 2012, from: http://www.scribd.com/ doc/39018798/Biodegradable-Polymers.

Prasanna, V., Prabha, T. N., Tharanathan, R. N. (2007). Fruit ripening phenomena-an overview. Crit. Rev. Food Sci. Nutr., 4 (1), 1-19. 
Pristijono, P., Wills, R. B., Golding, J. B. (2006). Inhibition of browning on the surface of apple slices by short term exposure to nitric oxide (NO) gas. Postharv. Biol. Technol., 42, 256-259.

Quevedo, R., Díaz, O., Cuqueo, A., Ronceros, B., Aguilera, J. M. (2009). Quantification of enzymatic browning kinetics in pear slices using non-homogenous L* colour information from digital images. Food Sci. Technol., 42, 1367-1373.

Rico, D., Martin-Diana, A. B., Barat, J. M., Barry-Ryan, C. (2007). Extending and measuring the quality of fresh-cut fruits and vegetables: A review. Trends Food Sci. Technol., 18, 373-386.

Rößle C., Gormley T. R., Buttler F. (2009). Efficacy of Natureseal® AS1 browning inhibitor in fresh-cut fruit salads applications, with emphasis on apple wedges. J. Horticult. Sci. Biotechnol. ISAFRUIT, Spec. Issue, 62-67.

Rocha, A. M. C. N., Morais, A. M. M. B. (2003). Shelf life of minimally processed apple (cv. Jonagored) determined by colour changes. Food Control, 14, 13-20.

Rodriguez-Aguilera, R., Oliveira, C. J. (2009). Review of design engineering methods and applications of active and modified atmosphere packaging cystems. J. Food Engin., 1, 66-83.

Rojas-Graü, M. A., Sobrino-López, A., Tapia, M. S., Martḳn-Belloso, O. (2006). Browning inhibition in fresh-cut 'Fuji' apple slices by natural antibrowning agents. J. Food Sci., 71 (1), 59-65.
Rojas-Graü, M. A., Soliva-Fortuny, R., Martżn-Belloso, O. (2009). Edible coatings to incorporate active ingredients to fresh cut fruits: A review. Trends Food Sci. Technol., 20, 438-447.

Sandhya (2010). Modified atmosphere packaging of fresh produce: Current status and future needs. Food Sci. Technol., 43, 381-392.

Soliva-Fortuny, R. C., Grigelmo-Miguel, N., Hernando, I. (2002). Effect of minimal processing on the textural and structural properties of fresh-cut pears. J. Sci. Food Agric., 82, 1682-688.

Son, S. M., Moon, K. D., Lee, C. Y. (2000). Rhubarb juice as a natural antibrowning agent. J. Food Sci., 65 (7), 1288-1289.

Suttirak, W., Manurakchinakor, S., Walailak, J. (2010). Potential application of ascorbic acid, citric acid and oxalic acid for browning inhibition in fresh-cut fruits and vegetables. Sci. Technol., 7 (1), 5-14.

Theerakulkait, C., Sukhonthara, S. (2008). Effect of pineapple juice, pineapple shell extract and rice bran extract on browning prevention in banana [Musa (AAA Group) 'Gros Michel'] Slices and Puree. Kasetsart J. (Nat. Sci.), 42, 150-55.

Toivonen, P. M. A., Brummell, D. (2008). Biochemical bases of appearance and textural changes in fresh-cut fruits and vegetables. Postharv. Biol. Technol., 48, 1-14.

Xiao, C., Liwei, Z., Wen, L., Xiaoyong, S., Yun, D. (2010). Combined action of pure oxygen pretreatment and chitosan coating incorporated with rosemary extracts on the quality of fresh-cut pears. Food Chem., 121, 1003-1009.

Received 3 December 2012

\section{PRETBRŪNĒŠANAS INHIBITORU UN BIODEGRADĒJAMO IEPAKOJUMU IETEKME UZ SVAIGI GRIEZTU BUMBIERU KVALITĀTI}

Grieztu aug̣̣u kvalitatīvo īpašību saglabāšanai realizācijas laikā tiek izmantoti pretbrūnēšanas apstrādes līdzekḷi — inhibitori. Iepakojums ir neatṇemama sastāvdaḷa pārtikas produktu ražošanas un mārketinga procesos. Pētījums veikts Latvijas valsts augḷkopības institūtā 2010. gadā. Pētījuma mērḳis bija novērtēt pretbrūnēšanas inhibitoru apstrādes efektivitāti (20\% krūmcidoniju sulas) salīdzinājumā ar $1.5 \%$ askorbīnskābes škīiduma (kontroles) un novērtēt biodegradējamo iepakojuma materiālu ietekmi uz apstrādāto griezto bumbieru kvalitāti uzglabāšanas laikāā, salīdzinot ar tradicionālo parasto iepakojumu — polietilēna (PE) maisiniem. Biodegradējamie polilaktīda (PLA) konteineri ar vākiem un VC999 BioPack PLA plēves, ar silīcija oksīda barjeru (SiOx) izmantotas grieztu bumbieru iepakošanai, bet kontroles paraugs iepakots PE plēves maisiṇos. Pētījuma laikā kontrolēta bumbieru kvalitāte, krāsa, cietība, pH, škīstošās sausnas saturs. Bumbieri (Pyrus communis) 'Belorusskaja Pozdnaja' nomizoti, sagriezti gabaliņos $(1-1.5 \mathrm{~cm})$ desmit minūtes mērcêti inhibitoru škīiumos (1.5\% askorbīnskābes šḳīdumā, 20\% krūmcidoniju sulas ūdens atšḳaidījumā). Augḷu gabalinii notecināti, iepakoti PE plēves maisiṇos, biodegradējamie iepakojumos: VC999 BioPack PLA maisinos un PLA kārbin̄ās. Paraugi uzglabāti $+4 \pm 1{ }^{\circ} \mathrm{C}$ temperatūrā devinas dienas. Pētìjuma rezultāti rāda, ka krāsa labāk saglabājusies svaigi grieztajiem bumbieriem biodegradējamā materiāla iepakojumos, kā arī pēc apstrādes ar 1.5\% askorbīnskābes škīiumu. L * vērtība svaigi grieztajiem bumbieriem pēc deviṇu dienu uzglabāšanas bija būtiski zemāka parastajos PE plēves maisiņos pēc apstrādes ar $20 \%$ krūmcidoniju sulu. 